OPEN ACCESS

Edited by: Hikmet Budak Montana State University,

United States

Reviewed by:

Concetta Lotti,

University of Foggia, Italy

Martin Mascher,

Leibniz-Institut für Pflanzengenetik und Kulturpflanzenforschung (IPK),

Germany

${ }^{*}$ Correspondence:

Lee Hickey

I.hickey@uq.edu.au

Specialty section:

This article was submitted to

Plant Breeding,

a section of the journal

Frontiers in Plant Science

Received: 21 November 2018

Accepted: 28 February 2019

Published: 25 March 2019

Citation:

Dinglasan E, Hickey L, Ziems L, Fowler R, Anisimova A, Baranova O, Lashina N and Afanasenko O (2019)

Genetic Characterization

of Resistance to Pyrenophora teres

f. teres in the International Barley

Differential Canadian Lake Shore.

Front. Plant Sci. 10:326.

doi: $10.3389 /$ fpls.2019.00326

\section{Genetic Characterization of Resistance to Pyrenophora teres f. teres in the International Barley Differential Canadian Lake Shore}

\author{
Eric Dinglasan ${ }^{1}$, Lee Hickey ${ }^{1 *}$, Laura Ziems ${ }^{1}$, Ryan Fowler ${ }^{1}$, Anna Anisimova ${ }^{2}$, \\ Olga Baranova ${ }^{2}$, Nina Lashina ${ }^{2}$ and Olga Afanasenko ${ }^{2}$ \\ ' Queensland Alliance for Agriculture and Food Innovation, The University of Queensland, St Lucia, QLD, Australia, \\ ${ }^{2}$ All-Russian Institute of Plant Protection, Saint Petersburg, Russia
}

Genetic resistance to net form of net blotch in the international barley differential Canadian Lake Shore (CLS) was characterized and mapped. A doubled haploid (DH) population generated from a cross between CLS and susceptible cultivar Harrington was evaluated at the seedling stage using eight diverse Pyrenophora teres f. teres (Ptt) isolates and at the adult stage in the field using natural inoculum. To effectively map the CLS resistance, comparative marker frequency analysis (MFA) was performed using 8,762 polymorphic DArT-seq markers, where 'resistant' and 'susceptible' groups each comprised $40 \mathrm{DH}$ lines displaying the most extreme phenotypes. Five DArTseq markers were consistently detected in eight disease assays, which was designated qPttCLS and deemed to harbor the locus underpinning CLS resistance. Four of these markers were present onto the barley DArTseq physical map and spans a region between 398203862 and 435526243 bp which were found to consist several genes involved in important plant functions such as disease response and signaling pathways. While MFA only detected the $3 \mathrm{H}$ region, genetic analyses based on segregation patterns were inconsistent, suggesting complex inheritance or variation in phenotypic expression of qPttCLS, particularly in the field. This study represents progress toward connecting Ptt pathotype surveys with the corresponding resistance genes in barley differentials. The markers associated with qPttCLS are useful for marker-assisted selection in breeding programs.

Keywords: net form net blotch, barley, QTL, genetic resistance, marker-assisted selection

\section{INTRODUCTION}

Net form of net blotch (NFNB) caused by ascomycete fungus Pyrenophora teres $\mathrm{f}$. teres (Ptt) is considered one of the most widespread and destructive diseases of barley (Hordeum vulgare L.) crops worldwide. For susceptible cultivars, NFNB can result in yield losses up to $40 \%$ (Steffenson et al., 1991; Murray and Brennan, 2010), and under extreme epidemic conditions may cause even higher losses, up to $70 \%$ (Wallwork et al., 2016). Still, the most effective means of control is the use of resistant cultivars. 
Resistance of barley to Ptt has been documented as both qualitative and quantitative resistance (Lai et al., 2007), suggesting a gene-for-gene interaction and complex genetic interactions, respectively. In both cases, resistance is attributed to the isolate of the pathogen.

Ptt is a highly diverse pathogen (Khan and Tekauz, 1982; Steffenson and Webster, 1992; Robinson and Jalli, 1997; Afanasenko, 2001; Serenius, 2006; Liu et al., 2012). However, the measure of virulence diversity is limited by the number of differential genotypes used in the tests (Wallwork et al., 2016). The barley cultivar, Canadian Lake Shore (CLS), has been used in numerous studies examining the virulence of local Ptt isolates in different barley growing regions around the world (Gray, 1966; Gacek, 1985; Steffenson, 1988; Steffenson and Webster, 1992; Afanasenko et al., 1995; Minarikova, 1995; Minarikova and Polisenska, 1999; Gupta and Loughman, 2001). Based on results from these studies, CLS is a good genotype for discriminating Ptt isolates. For this reason, CLS was included in the international set of barley differentials - established to standardize the characterization of Ptt populations globally (Afanasenko et al., 2009). However, knowledge of the genetic control(s) of resistance in CLS is unknown. This insight is essential to connect outcomes from pathogen virulence studies to genomic regions conferring resistance and/or susceptibility in the host. Such information will empower breeders to assemble effective host resistance in new barley cultivars.

In this study we performed genetic characterization of CLS resistance at both seedling and adult growth stages using diverse isolates sourced from Russia, Belarus, Germany, Canada, and South Africa. We examined a doubled haploid (DH) population derived from a cross between CLS and susceptible cultivar Harrington. Marker frequency analysis (MFA) was performed based on lines representing 'resistant' and 'susceptible' classes, in order to effectively map the CLS resistance and identify DNA markers useful for marker-assisted selection (MAS).

\section{MATERIALS AND METHODS}

\section{Plant Materials}

A total of 101 anther-culture-derived DH lines were developed from F1 plants of the cross between spring barley cultivars CLS and Harrington at the All Russian Research Institute for Plant Protection, Saint Petersburg, Russia. Anthers were cultured according to the method established by Manniner (1997). Notably, both of these cultivars are included in the international set of barley differentials: CLS is a resistant cultivar with good differential ability and Harrington is a susceptible check (Table 1) (Afanasenko et al., 2009).

\section{Pathogen Materials}

Eight Ptt isolates sourced from different origins were used for screening the DH population and parents in this study (Table 1). Isolates were obtained from infected barley leaves collected between 2011 and 2017. Leaves were surface sterilized with 3\% $\mathrm{CuSO}_{4}$ for $1 \mathrm{~min}$ and then double rinsed in sterile distilled
TABLE 1 | Details for the Pyrenophora teres f. teres isolates used in this study.

\begin{tabular}{|c|c|c|c|c|}
\hline Isolate & $\begin{array}{c}\text { Geographic } \\
\text { origin }\end{array}$ & Cultivar* & $\begin{array}{c}\text { Year } \\
\text { collected }\end{array}$ & Virulent/avirulent \\
\hline Len7 & $\begin{array}{l}\text { Leningrad } \\
\text { Region of } \\
\text { Russia }\end{array}$ & Inari & 2011 & $\begin{array}{l}\text { Harrington, Skiff, } \\
\text { k-20019, Cl5791, } \\
\text { k-8755/CLS, Harbin }\end{array}$ \\
\hline Ps31 & $\begin{array}{l}\text { Pskov } \\
\text { Region } \\
\text { of Russia }\end{array}$ & Suzdalets & 2014 & Harrington/CLS, Harbin \\
\hline Pr11 & $\begin{array}{l}\text { Primorie, } \\
\text { Far East } \\
\text { of Russia }\end{array}$ & Tikhookeanskiy & 2014 & $\begin{array}{l}\text { Harrington/CLS, Skiff, } \\
\text { Prior, k-20019, Harbin, } \\
\text { Cl9825, Cl5791, } \\
\text { k-8755 }\end{array}$ \\
\hline Bel1 & $\begin{array}{l}\text { Minsk } \\
\text { Region of } \\
\text { Belarus }\end{array}$ & Gonar & 2014 & $\begin{array}{l}\text { Harrington, Skiff, } \\
\text { k-20019/CLS, Prior, } \\
\text { Harbin, Cl9825, } \\
\text { Cl5791, k-8755 }\end{array}$ \\
\hline Vol13 & $\begin{array}{l}\text { Leningrad } \\
\text { Region of } \\
\text { Russia }\end{array}$ & Suzdalets & 2014 & $\begin{array}{l}\text { Harrington, Skiff, Prior, } \\
\text { k-20019/CLS, Harbin, } \\
\text { Cl9825, Cl5791, } 8755\end{array}$ \\
\hline G5 & Germany & NA & 2015 & $\begin{array}{l}\text { Harrington, k-8755, } \\
\text { Cl9825, Skiff, } \\
\text { Prior/CLS, Harbin, } \\
\text { Cl5791, k-20019 }\end{array}$ \\
\hline Can11 & Canada & Harrington & 2012 & $\begin{array}{l}\text { Harrington, Cl9825, } \\
\text { Skiff, Prior/k-8755, } \\
\text { CLS, Harbin, Cl5791, } \\
\text { k-20019 }\end{array}$ \\
\hline SA7 & South Africa & NA & 2017 & $\begin{array}{l}\text { Harrington, Cl9825, } \\
\text { Skiff, Prior/k-8755, } \\
\text { CLS, Harbin, Cl5791, } \\
\text { k-20019 }\end{array}$ \\
\hline
\end{tabular}

* Cultivar on which the isolate was collected; NA - cultivar information not available.

water. Isolates were propagated on Czapek's modified medium containing the following: $0.5 \mathrm{~g} / \mathrm{L} \mathrm{KH}_{2} \mathrm{PO}_{4}, 0.5 \mathrm{~g} / \mathrm{L} \mathrm{MgSO}_{4}, 0.5 \mathrm{~g} / \mathrm{L}$ $\mathrm{KCl}, 1.2 \mathrm{~g} / \mathrm{L}$ urea, $20 \mathrm{~g} / \mathrm{L}$ lactose, and $20 \mathrm{~g} / \mathrm{L}$ agar. The Petri dishes were incubated for 10 days at $20 \pm 2{ }^{\circ} \mathrm{C}$ under constant illumination with a daylight lamp (3000 lux). Single conidia were transferred to the same medium and incubated at the same conditions for 10-12 days. Based on preliminary screening, all isolates were avirulent to CLS.

\section{Fungal Preparation and Inoculation of Seedlings}

The cultures were flooded with distilled water containing $0.01 \%$ TWEEN $^{\circledR} 20$ and conidia were dislodged with a sterile spatula. The spore suspension was filtered through gauze. The spore concentration of the suspension was determined by means of a hemocytometer and adjusted to 5,000 conidia per $\mathrm{ml}$ for inoculation.

Evaluation of resistance of $\mathrm{DH}$ lines was assayed using the detached leaf method (Afanasenko et al., 1995). Barley seedlings were grown on cotton soaked in water in enameled trays for $8-10$ days at $20-22^{\circ} \mathrm{C}$ with alternating $12 \mathrm{~h}$ periods of light (exposure 3000 lux) and dark. Primary leaves were excised and 4-5 cm long segments and were placed in enamel trays $(27 \mathrm{~cm} \times 33 \mathrm{~cm})$ on filter paper moistened with sterile 
water containing $0.004 \%$ benzimidazole. For each $\mathrm{DH}$ line, leaf segments from two seedlings in four repetitions (total eight seedlings) were placed on the filter paper in different trays. Resistant and susceptible parents were placed in each tray. Inoculation was performed by spraying suspension at a rate of $1 \mathrm{ml}$ per 20 leaf segments. The trays were covered with glass plates and returned to the same light and temperature conditions as used for growing the seedlings.

\section{Scoring Seedling Infection Response}

Five days post-inoculation, the infection response (IR) was recorded using the 10-point scale of Tekauz (1985). For analysis of segregation patterns, lines displaying an average IR of $\leq 4.9$ were considered resistant, and $\geq 5$ were considered susceptible.

\section{Adult Plant Screening in the Field}

The $\mathrm{DH}$ lines and two parents Harrington and CLS were screened in 2015 at the adult plant stage in the field, located at the State Cultivars Screening Nursery "Volosovo," Leningrad Region, Russia. Ptt is endemic at this location and net blotch epidemics are observed each year. Lines were planted in $1 \mathrm{~m}$ rows (15-20 seeds) in a randomized block design with two replications per line. Parents were planted at the beginning and end of every 10 rows. In order to promote disease development two rows of the highly susceptible cultivar Carlsberg were planted around the experimental plots. No artificial inoculum and no herbicides were applied. NFNB reaction was scored at the growth stage of GS75 ( $6^{\text {th }}$ to $8^{\text {th }}$ August 2015 ) using a 1-9 scale, where $1=$ very resistant, and $9=$ very susceptible.

\section{Genotyping and Comparative Marker Frequency Analysis}

Genomic DNA was extracted for a subset of $94 \mathrm{DH}$ lines and the two parents using the protocol recommended by Diversity Arrays Technology Pty Ltd. (DArT ${ }^{1}$ ). The samples were genotyped using the Barley GBS 1.0 platform, which returned 8,762 polymorphic silico DArTseq markers.

Marker data was subjected to a quantitative allele frequency analysis technique, known as comparative MFA (Ziems et al., 2017), to identify quantitative trait loci (QTL) associated with Ptt resistance. The frequency of alleles contributing resistance (R) contributed by CLS was compared with the frequency of alleles contributing susceptibility (S) by Harrington in the segregating $\mathrm{DH}$ progeny. A discriminant value reflecting the difference in allele frequency between the two classes was obtained for each marker according to Wenzl et al. (2006, 2007). This approach can effectively identify genetic loci influencing a trait of interest without the need to generate a linkage map (Wenzl et al., 2007). Each phenotypic class ( $\mathrm{R}$ or $\mathrm{S}$ ) comprised $40 \mathrm{DH}$ lines that displayed the most extreme phenotypes in each disease assay. Each marker was subjected to a simple Chi-squared test to detect significant discrimination between the expected and observed allele frequencies. A differential threshold of $>0.4$ discriminant

${ }^{1}$ www.diversityarrays.com value and $P<0.001$ for a marker to be considered associated was determined, ensuring there is a $0.1 \%$ probability of detecting an allele frequency difference by chance.

The genomic intervals containing associated DArT-seq markers were displayed on the barley DArTseq consensus map and positioned onto the barley DArTseq physical map using Pretzel (Keeble-Gagnère et al., 2019).

The genomic interval of interest harboring the locus associated with Ptt response was searched for the presence of genes through EnsemblPlants database using the barley genome assembly Hordeum vulgare (IBSC_v2) of the International Barley Genome Sequencing Consortium ${ }^{2}$.

\section{RESULTS}

\section{Seedling Response to Ptt Isolates}

The resistant parent CLS displayed a low IR across all disease assays (ranging 1.0-4.4), and susceptible parent Harrington displayed a high IR in all assays (ranging 7.0-10.0; Figures 1, 2, Table 2 and Supplementary Table 1). The segregation ratio for four of the eight isolates (i.e., Len7, Ps31, Vol13, and G5) appeared consistent with a single gene inheritance model (i.e., 1:1, Table 2). However, Mendelian analyses based on division of the progeny to susceptible and resistant classes could not explain the segregation pattern observed for isolates Bel1,Pr11, Can11, and SA7 (Table 2).

The correlation between IRs observed for different Ptt isolates in the $\mathrm{DH}$ progeny varied from 0.26 to 0.78 (Table 3 ). The highest degree of correspondence $(r=0.78)$ was found between IR to isolates from Far East of Russia (Pr11) and Pskov Region (Ps31) and the lowest correspondence observed $(r=0.26)$ for IR to isolates from Belarus (Bel1) and Germany (G5) (Table 3).

\section{Adult Plant Stage Screening in the Field}

In the field experiment, NFNB severity on the susceptible cultivar Carlsberg reached 50-60\% leaf area infected at the time of assessment. The IR of the susceptible parent Harrington was also high (7.5 on 1-9 scale). As expected, the IR of the resistant parent CLS was low (3.0) (Supplementary Table 1).

When evaluated at the adult plant stage in the field, the CLS/Harrington DH population displayed a bi-modal distribution of resistance to $\mathrm{Ptt}$ (Figure 1). Unlike results from the seedling assays, segregation of resistance did not fit a single gene model, but instead fitted to a 1:3 (R:S) ratio, suggesting a two complementary gene inheritance model (Table 2). Interestingly, only one $\mathrm{DH}$ line displayed a lower IR than the resistant parent CLS. High correlations (0.71-0.77) between adult plant reaction in the field and seedling reaction were observed for five isolates: Len7, Ps31, Pr11, Can11, and SA7 (Table 3). The lowest correlation between adult plant reaction and seedling reaction was found for the isolate from Germany (G5, 0.40).

\footnotetext{
${ }^{2}$ https://plants.ensembl.org/Hordeum_vulgare/Info/Index?db=core
} 


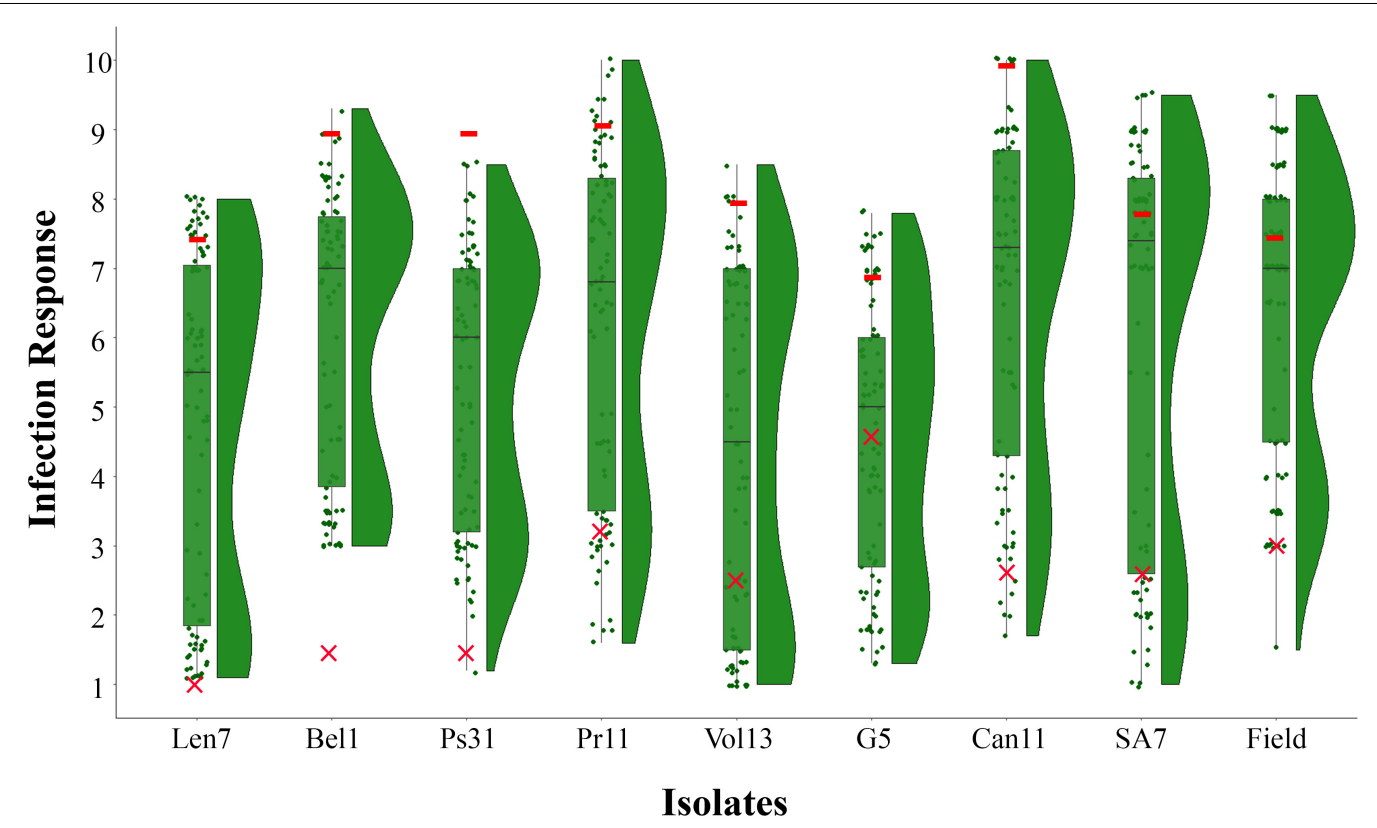

FIGURE 1 | Frequency distribution of infection responses (IRs) in the CLS/Harrington DH population evaluated using eight Pyrenophora teres f. teres isolates at the seedling stage (Len7, Bel1, Ps31, Pr11, Vol13, G5, Can11, and SA7) and natural inoculum at the adult stage in the field. Box plots show upper and lower quartile where horizontal line represents median IR and overlaid is the raw data points; split violin plots represent the density estimates related to the distribution of CLS/Harrington DH population in each assay. Symbols colored in red indicate mean IR displayed by parental genotypes (- Harrington; $\times-$ CLS) in each assay.
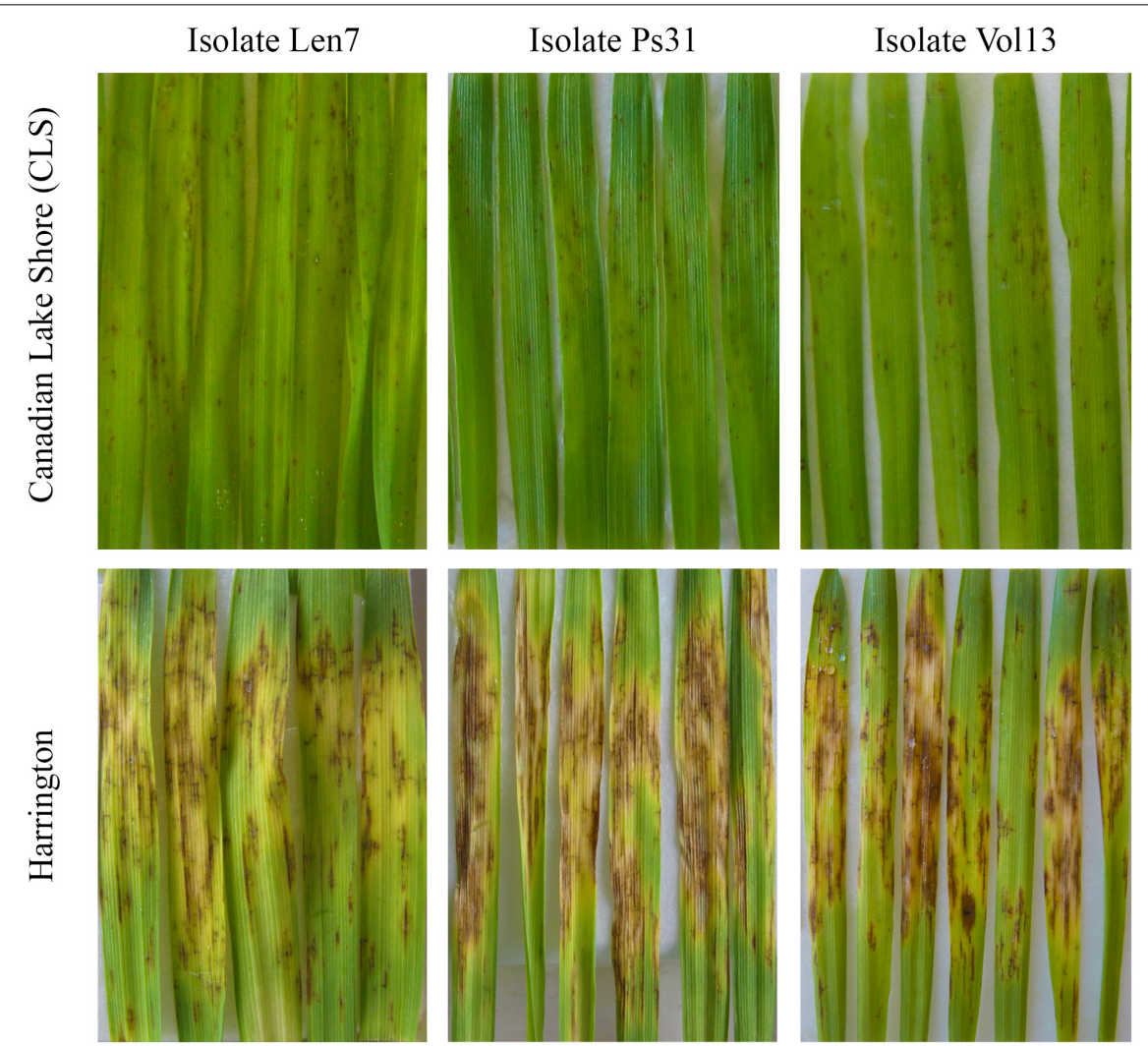

FIGURE 2 | Infection response for parental lines (Canadian Lake Shore and Harrington) for representative isolates of Pyrenophora teres f. teres (i.e., Len7, Ps31, and Vol13). Leaves from seedlings are displayed. 
TABLE 2 | The infection response (IR) of doubled haploid (DH) progeny and parents to different Pyrenophora teres f. teres isolates.

\begin{tabular}{|c|c|c|c|c|c|c|c|c|c|}
\hline \multirow[t]{2}{*}{ Isolate } & \multicolumn{2}{|c|}{ IR of DH lines } & \multicolumn{2}{|c|}{ IR of parents } & \multirow{2}{*}{ Res } & \multirow{2}{*}{ Sus } & \multirow{2}{*}{$\begin{array}{c}\text { Genetic } \\
\text { ratio }\end{array}$} & \multirow{2}{*}{$\begin{array}{c}\text { Chi } \\
\text { square }\end{array}$} & \multirow[t]{2}{*}{$P$-value } \\
\hline & Minimum & Maximum & CLS & Harrington & & & & & \\
\hline Len7 & 1.1 & 8.0 & 1.0 & 7.0 & 41 & 57 & $1: 1$ & 2.61 & 0.106 \\
\hline Bel1 & 3.0 & 9.3 & 1.5 & 9.0 & 32 & 66 & $1: 1$ & 11.80 & 0.001 \\
\hline Ps31 & 1.2 & 8.5 & 1.5 & 9.0 & 41 & 57 & $1: 1$ & 2.61 & 0.106 \\
\hline $\operatorname{Pr} 11$ & 1.6 & 10.0 & 2.4 & 8.0 & 33 & 63 & $1: 1$ & 9.38 & 0.002 \\
\hline Vol13 & 1.0 & 8.5 & 3.2 & 8.9 & 47 & 49 & $1: 1$ & 0.04 & 0.838 \\
\hline G5 & 1.3 & 7.8 & 4.4 & 7.0 & 47 & 42 & $1: 1$ & 0.28 & 0.596 \\
\hline Can11 & 1.7 & 10.0 & 2.5 & 10.0 & 25 & 61 & $1: 1$ & 15.07 & 0.000 \\
\hline SA7 & 1.0 & 9.5 & 2.3 & 7.8 & 28 & 54 & $1: 1$ & 8.24 & 0.004 \\
\hline Field* & 1.5 & 9.5 & 3.0 & 7.5 & 27 & 68 & $1: 3$ & 0.59 & 0.441 \\
\hline
\end{tabular}

The results from Chi-squared $\left(\mathrm{x}^{2}\right)$ analyses are also presented.

* Natural inoculum evaluated at the adult growth stage.

Res $=$ resistant; Sus = susceptible.

$P 5 \%=3.84$ at $1 \mathrm{df}$.

TABLE 3 | Correlation (r) between infection responses observed for different Pyrenophora teres f. teres isolates in the CLS/Harrington doubled haploid population.

\begin{tabular}{lcccccccc}
\hline Isolates & Bel1 & Ps31 & Pr11 & Vol13 & G5 & Can11 & SA7 & Field* \\
\hline Len7 & \multirow{2}{*}{0.52} & 0.66 & 0.68 & 0.69 & 0.46 & 0.70 & 0.73 & 0.71 \\
Bel1 & & 0.68 & 0.61 & 0.51 & 0.26 & 0.56 & 0.48 & 0.52 \\
Ps31 & & & 0.78 & 0.66 & 0.45 & 0.74 & 0.72 & 0.75 \\
Pr11 & & & & 0.71 & 0.37 & 0.70 & 0.63 & 0.71 \\
Vol13 & & & & & 0.44 & 0.64 & 0.64 & 0.69 \\
G5 & & & & & 0.32 & 0.42 & 0.40 \\
Can11 & & & & & & & 0.77 & 0.76 \\
SA7 & & & & & & & & 0.77 \\
\hline
\end{tabular}

*Natural inoculum evaluated at the adult growth stage.

TABLE 4 | Summary of resistant (R) and susceptible (S) classes used for Marker Frequency Analysis for the six Pyrenophora teres f. teres assays.

\begin{tabular}{|c|c|c|c|c|}
\hline Assay & Class & $N$ & Mean IR & $S D$ \\
\hline \multirow[t]{2}{*}{ Field* } & $\mathrm{R}$ & 40 & 4.5 & 1.5 \\
\hline & S & 40 & 8.2 & 0.7 \\
\hline \multirow[t]{2}{*}{ Pr11 } & $\mathrm{R}$ & 40 & 3.8 & 1.4 \\
\hline & $S$ & 40 & 8.5 & 0.7 \\
\hline \multirow[t]{2}{*}{ Ps31 } & $\mathrm{R}$ & 40 & 3.3 & 0.9 \\
\hline & S & 40 & 7.2 & 0.6 \\
\hline \multirow[t]{2}{*}{ Bel1 } & $\mathrm{R}$ & 40 & 4.2 & 1.2 \\
\hline & S & 40 & 7.9 & 0.6 \\
\hline \multirow[t]{2}{*}{ Len7 } & $\mathrm{R}$ & 40 & 2.3 & 1.3 \\
\hline & $S$ & 40 & 7.1 & 0.7 \\
\hline \multirow[t]{2}{*}{ Vol13 } & $\mathrm{R}$ & 40 & 1.8 & 0.9 \\
\hline & S & 40 & 7.0 & 0.7 \\
\hline \multirow[t]{2}{*}{ G5 } & $\mathrm{R}$ & 40 & 2.7 & 0.9 \\
\hline & S & 40 & 6.4 & 0.3 \\
\hline \multirow[t]{2}{*}{ Can11 } & $\mathrm{R}$ & 40 & 4.4 & 1.7 \\
\hline & $S$ & 40 & 8.7 & 0.7 \\
\hline \multirow[t]{2}{*}{ SA7 } & $\mathrm{R}$ & 40 & 3.6 & 2.2 \\
\hline & $S$ & 40 & 8.4 & 0.6 \\
\hline
\end{tabular}

*Natural inoculum evaluated at the adult growth stage.

\section{Genomic Regions Associated With Resistance}

The mean IR for 'resistant' and 'susceptible' classes was clearly differentiated across the six disease assays (Table 4). Comparative MFA identified 251 DArTseq markers associated with resistance to all isolates, except G5. These markers span a region of $36.26-76.56 \mathrm{cM}$ on chromosome $3 \mathrm{H}$ of the barley consensus genetic map (Supplementary Table 2). Marker $4016922(44.74 \mathrm{cM})$ was identified to be the most significant $(P=1.80 \mathrm{E}-18)$ and had the highest discriminant value $(\mathrm{D}=0.74)$, followed by 3270940 (50.50 cM; $P=2.40 \mathrm{E}-16, \mathrm{D}=0.61)$ which was associated in seedling response to isolates Vol13 and PS31, respectively. In the field, marker 3268587 was the most significant $(P=2.30 \mathrm{E}-17)$ and the highest discriminant value $(\mathrm{D}=0.67)$. Alleles contributing resistance were donated by resistant parent CLS. Five DArT-seq markers were consistently detected in eight disease assays, positioned within a smaller window of $0.5 \mathrm{cM}$ ranging from 51.27 to $51.77 \mathrm{cM}$ (Figure 3 and Table 5). We designated this QTL region $q$ PttCLS.

From these five markers, four $(3255462$, 3257991, 3272635, and 4190028) were positioned onto the barley physical map spanning an interval region between 398203862 and 435526175 bp. This region was found to harbor 179 genes (Supplementary Table 3) of which 27 genes with annotated functions are involved in plant disease response, cell death, and signaling pathways (Table 6).

\section{DISCUSSION}

In this study we identified a major genomic region ( $q$ PttCLS) conferring resistance to $P t t$ in the international barley differential CLS. Although segregation for resistance was consistent with a single gene when the DH population was evaluated at the seedling stage using some isolates, this model did not fit all seedling datasets and segregation observed at the adult stage in the field suggested a two complimentary gene model. Thus, while we have identified a key genomic region conferring resistance to $P t t$ in CLS, stable expression could be more complex and may involve additional genetic factors, particularly at the adult growth stage.

The high degree of variation of $\mathrm{Ptt}$ is highlighted in numerous studies using both virulence markers (Tekauz, 1990; Steffenson and Webster, 1992; Afanasenko et al., 2009; Jalli, 2010) and molecular markers (Peever and Milgroom, 1994; Rau et al., 2003; Serenius, 2006). CLS is one of nine genotypes included in the international set of barley differentials, which is used to characterize populations and virulence phenotypes of Ptt (Afanasenko et al., 2009). This core set of genotypes is essential to track changes in the pathogen population in the different barley growing regions around the world. A major objective is to identify the loci underpinning resistance in all differential genotypes. This insight will identify differentials that carry identical genes or haplotypes conferring resistance, and results from pathogen surveys can then be linked directly to characterized resistance genes in the host.

Mode and Schaller (1958) first reported CLS to carry resistance to Ptt and based on their inheritance studies, CLS 


\section{Chr 3H}

\section{Consensus map}

$\mathrm{cM}$

\section{DArTseq physical map}

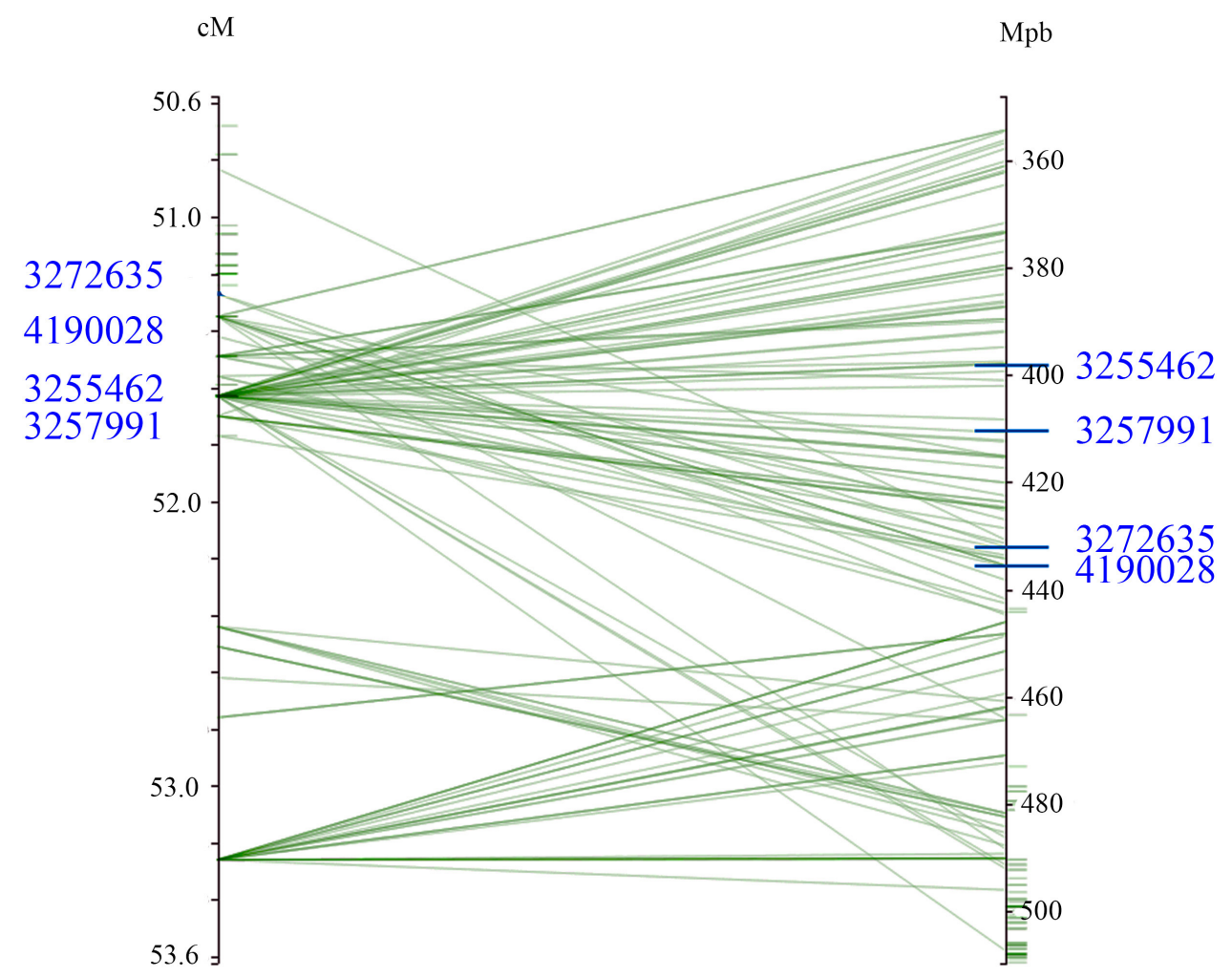

FIGURE 3 | Genomic interval containing associated DArTseq markers on Chromosome 3H. The DArTseq consensus map was aligned into the barley DArTseq physical map. For visual purposes, marker interval spanning the 50.6-53.6 cM was projected. The four DArTseq markers (blue) displayed on the chromosome, designated as qPttCLS, were consistently detected in all eight assays and were present in both the consensus and physical maps. The four markers defined an interval region spanning 398203862-435526243 bp onto the physical map.

TABLE 5 | Genetic position and discriminant values for the subset of DArT-seq markers that were consistently detected in eight marker frequency analyses performed in this study.

\begin{tabular}{|c|c|c|c|c|c|c|c|c|c|c|}
\hline CloneID & Allele sequence & $\begin{array}{c}\text { Genetic } \\
\text { position } \\
\text { (cM) }\end{array}$ & Field* & \multicolumn{7}{|c|}{ Seedling } \\
\hline 3272635 & $\begin{array}{l}\text { TGCAGGTTATACCCTCTTCTTAGGCTCCCGTGGCTT } \\
\text { TGACTCAGCCTTCTTGATGCCGCCCTTGGCGGC }\end{array}$ & 51.27 & 0.66 & 0.54 & 0.57 & 0.44 & 0.50 & 0.67 & 0.46 & 0.42 \\
\hline 3255462 & $\begin{array}{l}\text { TGCAGAGATCCTTATATCTGATITGGTITCTTAGA } \\
\text { GAGGATTCTCCTGAATCTCTTGGTCGGATTGA }\end{array}$ & 51.63 & 0.66 & 0.51 & 0.57 & 0.41 & 0.47 & 0.67 & 0.46 & 0.45 \\
\hline 4793115 & $\begin{array}{l}\text { TGCAGCGGAGCTGGGGACGGCGGCGTGATCCGAGAT } \\
\text { CGGAAGAGCGGTTCAGCAGGAATGCCGAGACCG }\end{array}$ & 51.63 & 0.63 & 0.45 & 0.55 & 0.40 & 0.48 & 0.62 & 0.44 & 0.43 \\
\hline 3257991 & $\begin{array}{l}\text { TGCAGCACCTCATCGACCTTTCCTCCTCTCCGTCCC } \\
\text { TGCACCCTCTGTGAGCAGCGCAGCCCCGCCTCC }\end{array}$ & 51.77 & 0.62 & 0.48 & 0.54 & 0.41 & 0.47 & 0.70 & 0.46 & 0.45 \\
\hline
\end{tabular}

All five markers were significantly associated with resistance to $P$. teres on Chromosome $3(P<0.001)$ and mark the 0.5 cM region containing qPttCLS donated by Canadian Lake Shore.

*Natural inoculum evaluated at the adult growth stage. 
TABLE 6 | List of 27 genes defined by the four (4) DArTseq markers ( $q$ PttCLS) positioned onto the barley physical map on the interval region 398203862-435526243 bp.

\begin{tabular}{|c|c|c|}
\hline Gene ID & Description & Function \\
\hline HORVU3Hr1G053990 & - & $\begin{array}{l}\text { Defense response, cell death, } \\
\text { ethylene biosynthetic process, } \\
\text { leaf senescence }\end{array}$ \\
\hline HORVU3Hr1G054090 & - & Transferase activity \\
\hline HORVU3Hr1G054120 & - & Gene silencing by RNA \\
\hline HORVU3Hr1G055130 & $\begin{array}{c}\text { Cytochrome c } \\
\text { oxidase subunit } 3\end{array}$ & Aerobic electron transport chain \\
\hline HORVU3Hr1G055260 & - & DNA binding \\
\hline HORVU3Hr1G055330 & - & Lipid metabolic process \\
\hline HORVU3Hr1G055410 & - & $\begin{array}{l}\text { Protein transport, positive } \\
\text { regulation of signaling }\end{array}$ \\
\hline HORVU3Hr1G055450 & - & $\begin{array}{l}\text { Integral component of } \\
\text { membrane }\end{array}$ \\
\hline HORVU3Hr1G055550 & - & Protein coding \\
\hline HORVU3Hr1G055620 & - & Protein kinase activity \\
\hline HORVU3Hr1G055630 & - & $\begin{array}{l}\text { Motor activity in plasma } \\
\text { membrane }\end{array}$ \\
\hline HORVU3Hr1G055650 & - & Protein coding \\
\hline HORVU3Hr1G055700 & $\begin{array}{l}\text { Uroporphyrinogen } \\
\text { decarboxylase }\end{array}$ & $\begin{array}{l}\text { Uroporphyrinogen } \\
\text { decarboxylase activity; lyase } \\
\text { activity }\end{array}$ \\
\hline HORVU3Hr1G055870 & - & Protein coding \\
\hline HORVU3Hr1G055900 & - & Response to dessication \\
\hline HORVU3Hr1G055920 & - & Protein coding \\
\hline HORVU3Hr1G055990 & $\begin{array}{l}\text { Beta-adaptin-like } \\
\text { protein }\end{array}$ & $\begin{array}{l}\text { Intercellular or vesicle-mediated } \\
\text { protein transport }\end{array}$ \\
\hline HORVU3Hr1G056200 & $\begin{array}{l}\text { Mitogen-activated } \\
\text { protein kinase }\end{array}$ & $\begin{array}{l}\text { MAPK cascade; protein } \\
\text { phosphorylation }\end{array}$ \\
\hline HORVU3Hr1G056440 & Pectinesterase & Cell wall modification \\
\hline HORVU3Hr1G056560 & - & $\begin{array}{l}\text { Flavonoid biosynthetic process; } \\
\text { oxidation-reduction process }\end{array}$ \\
\hline HORVU3Hr1G056990 & $\begin{array}{l}\text { Carbonic } \\
\text { anhydrase }\end{array}$ & Carbon utilization \\
\hline HORVU3Hr1G057010 & CASP-like protein & $\begin{array}{l}\text { Integral component of } \\
\text { membrane }\end{array}$ \\
\hline HORVU3Hr1G057090 & $\begin{array}{l}\text { Carbonic } \\
\text { anhydrase }\end{array}$ & Carbon utilization \\
\hline HORVU3Hr1G057630 & $\begin{array}{l}\text { Auxin efflux carrier } \\
\text { component }\end{array}$ & $\begin{array}{l}\text { Auxin-activated signaling } \\
\text { pathway }\end{array}$ \\
\hline HORVU3Hr1G057660 & $\begin{array}{l}\text { Mitogen-activated } \\
\text { protein kinase }\end{array}$ & $\begin{array}{l}\text { MAPK cascade; protein } \\
\text { phosphorylation }\end{array}$ \\
\hline HORVU3Hr1G057690 & - & $\begin{array}{l}\text { Monolayer-surrounded lipid } \\
\text { storage body; integral } \\
\text { component of membrane }\end{array}$ \\
\hline HORVU3Hr1G057840 & - & Zinc-ion binding protein \\
\hline
\end{tabular}

The corresponding description and functions are based on the database search on EnsembIPlants using the barley genome assembly Hordeum vulgare (IBSC_v2) of the International Barley Genome Sequencing Consortium. Only the genes at the start and end position of marker interval, and genes with annotated description were searched for biological, cellular, and molecular functions.

appeared to contribute two major resistance genes (Pt2 and Pt3). However, more recent studies examining CLS in populations derived from crosses to susceptible cultivars Pirkka and Nadja, observed segregation patterns consistent with a single gene conferring resistance (unpublished data). Although results from genetic analyses based on segregation patterns were variable in this study, the comparative MFA performed for each assay, identified a single major genomic region on Chromosome $3 \mathrm{H}$. Further, correlations between all disease assays were high, except in G5. This seems to point toward variability in levels of resistance conferred by the qPttCLS locus. This may explain the distorted segregation pattern observed for isolates Bel1, Pr11, Can11, and SA7; and the ineffectiveness of qPttCLS against isolate G5. After all, segregation analyses are based on a threshold applied to 'resistance' based on the observed IRs. This could also be the case for the adult assessment in the field, where a two complementary gene model was found to be significant based on Chi-squared analysis. While this suggests an additional gene may be involved, variation in expression of $q$ PttCLS could be influenced by environmental cues in the field, which could lead to low numbers of $\mathrm{DH}$ lines actually displaying high levels of resistance. Another plausible reason for this variation in IR could be the presence of isolate-specific minor resistance genes in CLS. A number of previous mapping studies have reported isolate specific QTL (Ho et al., 1996; Grewal et al., 2012; König et al., 2014; Afanasenko et al., 2015).

Several studies have detected QTL for resistance to Ptt on Chromosome 3H (Graner et al., 1996; Steffenson et al., 1996; Richter et al., 1998; Cakir et al., 2003; Raman et al., 2003; Yun et al., 2005; Manninen et al., 2006; Grewal et al., 2008; Gupta et al., 2010; Tenhola-Roininen et al., 2011; König et al., 2013, 2014; Afanasenko et al., 2015). Notably, the qPttCLS region of interest spans $51.27-51.77 \mathrm{cM}$ on $3 \mathrm{H}$ and QTL previously mapped to this chromosome can be compared using the consensus map provided by Aghnoum et al. (2010). For instance, Yun et al. (2005) reported Rpt-3H4 on the short arm of chromosome $3 \mathrm{H}(57.0-66.6 \mathrm{cM})$ via analysis of the OUH602/Harrington RIL population. Steffenson et al. (1996) reported a QTL in the Steptoe/Morex population (28.7-36.6 cM on 3H), which overlaps with the QTLUHs$3 \mathrm{H}-2$ region conferring seedling resistance to NFNB (34.0$38.0 \mathrm{cM}$ ) identified in detached leaf tests (König et al., 2014). Further, a QTL contributing adult plant resistance, QTLUH-3H (45-51 cM), was reported in the DH population Uschi/HHOR3073 (König et al., 2013). While these previously reported QTL are mapped in close proximity and in some cases overlapping with the region containing qPttCLS, allelism testing is required to precisely determine if the resistance gene is unique or common to these other sources. This future work will involve crossing CLS to these other sources carrying resistance genes mapped to $3 \mathrm{H}$ and testing for segregation of resistance in the progeny.

Aligning the DArTseq markers to the barley physical position allowed further analysis of annotated genes. The $q$ PttCLS region harbored genes that are involved in important plant biological, cellular, and molecular functions such as plant disease response, cell death, and signaling pathways. Interestingly, there are still many genes in this region that are uncharacterized, and thus further characterization is important that could potentially identify novel genes. The DArT-seq markers reported in this study will be useful 
for MAS targeting qPttCLS to develop barley cultivars resistant to NFNB.

\section{DATA AVAILABILITY}

The raw data supporting the conclusions of this manuscript will be made available by the authors, without undue reservation, to any qualified researcher.

\section{AUTHOR CONTRIBUTIONS}

ED and LZ analyzed the datasets and wrote the manuscript. $\mathrm{LH}$ coordinated data analyses and revised the manuscript. RF revised the data and contributed to manuscript writing. AA, OB, and NL performed the disease screens, DNA extraction, and lab work required for this study. OA designed the experiments and contributed to writing of the manuscript.

\section{REFERENCES}

Afanasenko, O. (2001). Investigations on populations of Pyrenophora teres f. teres, the cause of net blotch of barley. J. Russ. Phytopathol. 2, 9-18.

Afanasenko, O. S., Hartleb, H., Guseva, N. N., Minarikova, V., and Janosheva, M. A. (1995). A set of differentials to characterize populations of Pyrenophora teres Drechs. for international use. Phytopathology 143, 501-507. doi: 10.1111/j.14390434.1995.tb04562.x

Afanasenko, O. S., Koziakov, A. V., Hedlay, P. E., Lashina, N. M., Anisimova, A. V., Manninen, O., et al. (2015). Mapping of the loci controlling the resistance to Pyrenophora teres f. teres and Cochliobolus sativus in two double haploid barley populations. Russ. J. Genet. Appl. Res. 5, 242-253. doi: 10.1134/ S2079059715030028

Afanasenko, O., Jalli, M., Pinnschmidt, H., Filatova, O., and Platz, G. (2009). Development of an international standard set of barley differential genotypes for Pyrenophora teres f. teres. J. Plant Pathol. 58, 665-676. doi: 10.1111/j.13653059.2009.02062.x

Aghnoum, R., Marcel, T. C., Johrde, A., Pecchioni, N., Schweizer, P., and Niks, R. E. (2010). Basal host resistance of barley to powdery mildew: connecting quantitative trait loci and candidate genes. Mol. Plant Microbe Interact. 23, 91-102. doi: 10.1094/MPMI-23-1-0091

Cakir, M., Gupta, S., Platz, G. J., Ablett, G. A., Loughman, R., Embiri, L. S., et al. (2003). Mapping and validation of the genes for resistance to Pyrenophora teres f. teres in barley (Hordeum vulgare L.). Aust. J. Agric. Res. 54, 1369-1377. doi: 10.1071/AR02229

Gacek, E. (1985). Variabilities of pathogenicity of the Pyrenophora teres (Died) Drechsl Fungus. Hodowla Rosl. Aklim. Nasienn. 29, 41-50.

Graner, A., Foroughi-Wehr, B., and Tekauz, A. (1996). RFLP mapping of a gene in barley conferring resistance to net blotch (Pyrenophora teres). Euphytica 91, 229-234.

Gray, G. G. (1966). Genetic Systems in the Net Blotch Disease Complex of Barley. Ph.D. thesis, North Dakota State University, Fargo, 130.

Grewal, T. S., Rossnagel, B. G., Pozniak, C. J., and Scoles, G. J. (2008). Mapping quantitative trait loci associated with barley net blotch resistance. Theor. Appl. Genet. 116, 529-539. doi: 10.1007/s00122-007-0688-9

Grewal, T. S., Rossnagel, B. G., and Scoles, G. J. (2012). Mapping quantitative trait loci associated with spot blotch and net blotch resistance in a doubledhaploid barley population. Mol. Breed. 30, 267-279. doi: 10.1007/s11032-0119616-4

Gupta, S., Li, S. D., Loughman, R., Cakir, M., Platz, G., Westcott, S., et al. (2010). Quantitative trait loci and epistatic interactions in barley conferring resistance to net type net blotch Pyrenophora teres f. teres isolates. Plant Breed. 129, $362-368$.

\section{FUNDING}

This research was supported by the Russian Fund of Basic Research (14-04-00400).

\section{ACKNOWLEDGMENTS}

The authors are grateful to Dr. Gabriel Keeble-Gagnère (Agriculture Victoria) who assisted with aligning the DArTseq markers onto the barley reference genome.

\section{SUPPLEMENTARY MATERIAL}

The Supplementary Material for this article can be found online at: https://www.frontiersin.org/articles/10.3389/fpls.2019.00326/ full\#supplementary-material

Gupta, S., and Loughman, R. (2001). Current virulence of Pyrenophora teres on barley in Western Australia. Plant Dis. 85, 960-966. doi: 10.1094/PDIS.2001.85. 9.960

Ho, K. M., Tekauz, A., Choo, T. M., and Martin, R. A. (1996). Genetic studies on net blotch resistance in barley cross. Can. J. Plant Sci. 76, 715-719. doi: 10.4141/cjps96-123

Jalli, M. (2010). The Virulence of Finnish Pyrenophora teres $f$. teres Isolates and Its Implications for Resistance Breeding. Doctoral dissertation, MTT Plant Production Research, Jokionen, 45.

Keeble-Gagnère, G., Isdale, D., Suchecki, R., Kruger, A., Lomas, K., Carroll, D., et al. (2019). Integrating past, present and future wheat research with Pretzel. bioRxiv [Preprint]. doi: 10.1101/517953

Khan, T. N., and Tekauz, A. (1982). Occurrence and pathogenicity of Drechslera teres isolates causing spot type symptoms on barley in Western Australia. J. Plant Dis. 66, 423-425. doi: 10.1094/PD-66-423

König, J., Perovic, D., Kopahnke, D., and Ordon, F. (2013). Development of an efficient method for assessing resistance to the net type of net blotch (Pyrenophora teres f. teres) in winter barley and mapping of quantitative trait loci for resistance. Mol. Breed. 32, 641-650. doi: 10.1007/s11032-0139897-x

König, J., Perovic, D., Kopahnke, D., and Ordon, F. (2014). Mapping seedling resistance to net form of net blotch (Pyrenophora teres $\mathrm{f}$. teres) in barley using detached leaf assay. Plant Breed. 133, 356-365. doi: 10.1111/pbr.12147

Lai, Z., Faris, J. D., Weiland, J. J., Steffenson, B. J., and Friesen, T. L. (2007). Genetic mapping of Pyrenophora teres f. teres genes conferring avirulence on barley. Fungal Genet. Biol. 44, 323-329. doi: 10.1016/j.fgb.2006. 11.009

Liu, Z. H., Zhong, S., Stasko, A. K., Edwards, M. C., and Friesen, T. L. (2012). Virulence profile and genetic structure of a North Dakota population of Pyrenophora teres $\mathrm{f}$. teres, the causal agent of net form net blotch of barley. Phytopathology 102, 539-546. doi: 10.1094/PHYTO-09-11-0243

Manninen, O. M., Jalli, M., Kalendar, R., Schulman, A., Afanasenko, O., and Robinson, J. (2006). Mapping of major spot-type and net-type net blotch resistance genes in the Ethiopian barley (Hordeum vulgare) line CI 9819. Genome 49, 1564-1571. doi: 10.1139/g06-119

Manniner, O. (1997). Optimizing anther cuture for barley breeding. Agric. Food Sci. Finl. 6, 389-398. doi: 10.23986/afsci.72802

Minarikova, V. (1995). An analysis of Pyrenophora teres (Died.) Drechs. population in the Czech Republic and its use for barley resistance breeding. Ochrana Rostlin 31, 1-10.

Minarikova, V., and Polisenska, I. (1999). Analysis of populations of Pyrenophora teres on barley in the Czech Republic. J. Plant Prot. Sci. 35, 20-115. doi: 10.1016/ j.funbio.2013.11.008 
Mode, C. Y., and Schaller, C. W. (1958). Two additional factors for host resistance to net blotch in barley. J. Agron. 50, 8-15. doi: 10.2134/agronj1958. $00021962005000010005 x$

Murray, G. M., and Brennan, J. P. (2010). Estimating disease losses to the Australian barley industry. Aust. J. Plant Path. 39, 85-96. doi: 10.1071/AP09064

Peever, T. L., and Milgroom, M. G. (1994). Genetic structure of Pyrenophora teres populations determined with random amplified polymorphic DNA markers. Can. J. Bot. 72, 915-923. doi: 10.1139/b94-116

Raman, H., Platz, G. J., Chalmers, K., Raman, R., Read, B. J., Barr, A. R., et al. (2003). Mapping of genetic regions associated with net form of net blotch resistance in barley. Aust. J. Agric. Res. 54, 1359-1367. doi: 10.1071/AR03026

Rau, D., Brown, A. H. D., Brubaker, C. L., Attene, G., Balmas, V., Saba, E., et al. (2003). Population genetic structure of Pyrenophora teres Drechs. The causal agent of net blotch in Sardinian landraces of barley (Hordeum vulgare L.). Theor. Appl. Genet. 106, 947-959. doi: 10.1007/s00122-002-1173-0

Richter, K., Schondelmaier, J., and Jung, C. (1998). Mapping of quantitative trait loci affecting Drechslera teres resistance in barley with molecular markers. Theor. Appl. Genet. 97, 1225-1234. doi: 10.1007/s001220051014

Robinson, J., and Jalli, M. (1997). Quantitative resistance to Pyrenophora teres in six Nordic spring barley accessions. Euphytica 94, 201-208. doi: 10.1023/A: 1002996722383

Serenius, M. (2006). Population Structure of Pyrenophora teres the Causal Agent of Net Blotch of Barley. Doctoral dissertation, MTT Agrifood Research Finland, Jokioinen, 60 .

Steffenson, B. J. (1988). Investigations on Pyrenophora teres f. teres, the Cause of Net Blotch of Barley: Pathotypes, Host Resistance, Yield Loss and Comparative Epidemiology to Rhynchosporium secalis by time Series Analysis. Ph.D. thesis, University of California Davis, Davis, CA, 211.

Steffenson, B. J., Hayes, P. M., and Kleinhofs, A. (1996). Genetics of seedling and adult plant resistance to net blotch (Pyrenophora teres f. teres) and spot blotch (Cochliobolus sativus) in barley. Theor. Appl. Genet. 92, 552-558. doi: 10.1007/BF00224557

Steffenson, B. J., and Webster, R. K. (1992). Pathotype diversity of Pyrenophora teres f. teres. Phytopathology 82, 170-177. doi: 10.1094/Phyto-82-170

Steffenson, B. J., Webster, R. K., and Jackson, L. F. (1991). Reduction in yield loss using incomplete resistance to Pyrenophora teres f. teres in barley. J. Plant Dis. 75, 96-100. doi: 10.1094/PD-75-0096

Tekauz, A. (1985). A numerical scale to classify reactions of barley to Pyrenophora teres. Can. J. Plant Path. 7, 181-183. doi: 10.1080/07060668509501499
Tekauz, A. (1990). Characterization and distribution of pathogenic variation in Pyrenophora teres f. teres and P. teres f. maculata from Western Canada. Can. J. Plant Path. 12, 141-148. doi: 10.1080/07060669009 501017

Tenhola-Roininen, T., Jalli, M., Erkkila, M., Afanasenko, O., and Manninen, O. (2011). Mapping of Net Blotch Resistance Locus in Barley Line c-8755. Available at: http://www.hutton.ac.uk/sites/default/files/files/events/IWBLB/ Poster-Tenhola-Roininen.pdf

Wallwork, H., Butt, M., and Capio, E. (2016). Pathogen diversity and screening for minor gene resistance to Pyrenophora teres $\mathrm{f}$. teres in barley and its use for plant breeding. Aust. Plant Pathol. 45, 527-531. doi: 10.1007/s13313-0160433-4

Wenzl, P., Li, H., Carling, J., Zhou, M., Raman, H., Paul, E., et al. (2006). A highdensity consensus map of barley linking DArT markers to SSR, RFLP and STS loci and agricultural traits. BMC Genomics 7:206. doi: 10.1186/1471-21647-206

Wenzl, P., Raman, H., Wang, J. P., Zhou, M. X., Huttner, E., and Kilian, A. A. (2007). DArT platform for quantitative bulked segregant analysis. $B M C$ Genomics 8:196. doi: 10.1186/1471-2164-8-196

Yun, S. J., Gyenis, L., Hayes, P. M., Matus, I., Smith, K. P., Steffenson, B. J., et al. (2005). Quantitative trait loci for multiple disease resistance in wild barley. Crop Sci. 45, 2563-2572. doi: 10.2135/cropsci2005. 0236

Ziems, L. A., Hickey, L. T., Platz, G. J., Franckowiak, J. D., Dracatos, P. M., Singh, D., et al. (2017). Characterisation of Rph24: gene conferring adult plant resistance to Puccinia hordei in barley. Phytopathology 107, 834-841. doi: 10. 1094/PHYTO-08-16-0295-R

Conflict of Interest Statement: The authors declare that the research was conducted in the absence of any commercial or financial relationships that could be construed as a potential conflict of interest.

Copyright ( 2019 Dinglasan, Hickey, Ziems, Fowler, Anisimova, Baranova, Lashina and Afanasenko. This is an open-access article distributed under the terms of the Creative Commons Attribution License (CC BY). The use, distribution or reproduction in other forums is permitted, provided the original author(s) and the copyright owner(s) are credited and that the original publication in this journal is cited, in accordance with accepted academic practice. No use, distribution or reproduction is permitted which does not comply with these terms. 